\title{
PENGELOLAAN PASIEN HIV/AIDS
}

\author{
Yulia Ardiyanti ${ }^{1}$, Livana $\mathbf{P H}^{2}$ \\ ${ }^{1}$ STIKES Muhammadiyah Kendal \\ ${ }^{2}$ Program studi Ners Sekolah Tinggi Ilmu Kesehatan Kendal \\ liardiyanti1976@gmail.com
}

\begin{abstract}
Abstrak
Perawat pelaksana merupakan kunci keberhasilan dalam pengelolaan pasien HIV/AIDS untuk mewujudkan pelayanan keperawatan yang bermutu dan profesional. Tujuan penelitian ini adalah untuk mengetahui gambaran pengelolan pasien HIV/AIDS di RSUD dr. H. Soewondo Kendal. Penelitian dengan sampel 58 orang ini menggunakan rancangan deskriptif dengan pendekatan cross sectional dan uji normalitas data hasil penelitian menggunakan uji Kolmogorov Smirnov. Hasil penelitian menunjukkan bahwa Pengelolaan pasien HIV/AIDS oleh perawat pelaksana di RSUD dr. H. Soewondo Kendal sebagian besar berada pada kriteria baik yaitu sebanyak 53,4\%. Perlu ditingkatkan pengetahuan perawat tentang Universal Precaution dan pengendalian penyakit infeksi serta lebih meningkatkan rasa caring pada pasien dari pasien HIV/AIDS.
\end{abstract}

Kata kunci: HIV/AIDS, pengelolaan pasien

\begin{abstract}
The management of HIV / AIDS patients. Advocation nurses are the key to success in the management of HIV / AIDS patients to realize quality and professional nursing services. The purpose of this study was to determine the description of the management of HIV / AIDS patients in RSUD dr. H. Soewondo Kendal. The study with a sample of 58 people used a descriptive design with a cross sectional approach and the normality test of the results of the study using the Kolmogorov Smirnov test. The results of the study showed that the management of HIV / AIDS patients by implementing nurses in RSUD $d r$. H. Soewondo Kendal is mostly in good criteria, namely 53.4\%. Nurses need to improve their knowledge about Universal Precaution and control of infectious diseases and further increase the sense of caring in patients from HIV / AIDS patients.
\end{abstract}

Keywords: HIV/AIDS, Management of patients

\section{Pendahuluan}

Perawat sebagai petugas paling banyak berinteraksi dan kontak langsung dengan pasien memliki risiko terjadinya penularan penyakit lebih tinggi dibanding petugas kesehatan lainnya. Penggunaan alat pelindung diri yang baik merupakan salah satu upaya pencegahan penularan penyakir menular. Penyakit menular adalah penyakit infeksi yang didapat dari orang atau hewan sakit, dari benda-benda yang mengandung bibit penyakit lainnya ke manusia yang sehat. Salah satu jenis penyakit menular diantaranya adalah HIV/AIDS.

Berdasarkan data Kemenkes tentang angka kejadian HIV/AIDS, dari bulan Januari sampai September tahun 2014 kasus HIV di Indonesia terdapat 22. 869 orang, sedangkan kasus AIDS sebanyak 1876 orang. Data statistik yang ada dari tahun sebelumnya menunjukkan kenaikan jumlah penderita HIV di mana pada tahun 2013 kasus HIV sebanyak 21.511 orang. Penderita yang dilakukan perawatan di pelayanan kesehatan seperti Rumah Sakit atau Puskesmas pada tahun 2014 terdapat 12.527 orang. Jumlah kasus HIV di Jawa Tengah dari bulan Januari sampai September 2014 terdapat 2.069 orang, sedangkan penderita AIDS terdapat 428 orang ( Yayasan Spiritia. Data Statistik Kasus HIV/AIDS Di Indonesia. Diakses pada tanggal 30 Juni 2015 from http://spiritia.or.id/dokumum.php).

Penderita HIV AIDS di RSUD dr. H. Soewondo Kendal tahun 2014 untuk rawat jalan sebanyak 430 orang, sedangkan yang dirawat inap sebanyak 87 orang (Rekam medic RSUD H. Dr. Soewondho Kendal, 2015).

Risiko penularan HIV/AIDS terhadap tenaga kesehatan khususnya perawat sangat besar. Penelitian yang 
dilakukan di RS Mumbai India melaporkan bahwa $32,75 \%$ tenaga kesehatan terpapar HIV melalui darah dan cairan tubuh pasien, dan prosentase terbesar $(92,21 \%)$ adalah perawat. Pemaparan virus HIV oleh darah dan cairan tubuh pasien sebagian besar disebabkan melalui jarum suntik pada saat perawat melakukan tindakan perawatan pada pasien (Singru and Benerjee 2008). Penelitian Ibrahim tahun 2007 menunjukkan sebagian besar perawat melaporkan pernah mengalami kecelakaan kerja cedera benda tajam dengan jenis cedera terbanyak berupa tertusuk jarum suntik, diikuti tergores pecahan ampul, dan teriris pisau. Kecelakaan cedera yang paling sering terjadi ketika menutup kembali jarum suntik, membuka obat ampul, dan saat menusukkan jarum suntik ke botol obat.

Risiko penularan HIV/AIDS terhadap perawat dapat dicegah dengan memperluas pengetahuan dan perilaku yang baik bagi pasien yang terinfeksi HIV/AIDS. Perilaku perawat yang tidak membedakan saat memberikan perawatan antara pasien yang terinfeksi maupun tidak terinfeksi HIV/AIDS dapat memberikan arti yang cukup besar bagi kesembuhan pasien (Nursalam dan Ninuk 2018). Pelayanan asuhan keperawatan yang diberikan kepada pasien merupakan bentuk pelayanan professional yang bertujuan untuk memulihkan dan meningkatkan kemampuan diri pasien. Berdasarkan uraian diatas perlunya penelitian mengenai pengelolaan pasien HIV/AIDS di RSUD dr. H. Soewondo Kendal.

\section{Metode}

Jenis penelitian ini adalah penelitian deskriptif dangan pendekatan cross sectional. Penelitian dilakukan pada perawat pelaksana yang bekerja di ruang rawat inap yang pernah mengelola pasien HIV/AIDS. Pengambilan sampel penelitian ini adalah total populasi dengan kriteria inklusi pendidikan minimal D3 Keperawatan dan pernah mengelola pasien HIV/AIDS dakam 3 bulan terakhir. Sampel yang diperoleh terdapat 58 orang yang memenuhi criteria inklusi yang terbagi 29 perawat pelaksana ruang Cempaka dan 29 perawat pelaksana ruang Flamboyan.

Instrument penelitian dilakukan uji validitas dengan tujuan untuk mendapatkan data yang akurat dan objektif. Validitas isi (Content Validity) telah dilakukan oleh Dr. dr. Muchlis Achsan Udji Sofro, Sp.PDKPTI, Finasm. Staf RSUP dr. Karyadi Semarang yang dilakukan pada tanggal 5 dan 6 April 2016 dengan hasil Pada kuesioner nomor 17 dan 27 terdapat revisi kalimat dan terdapat tambahan satu item pertanyaann.

Kuesioner penelitian telah diuji cobakan di ruang rawat inap RSI Kendal dengan jumlah anggota sampel 30 orang pada tanggal 8-10 April 2016. Hasil uji validitas instrumen menunjukkan pada instrumen pengelolaan pasien HIV/AIDS sebanyak 35 pernyataan menunjukkan ada 10 pernyataan yaitu nomor $13,20,21,23,25,26,27,29,34$ dan 35 nilai $\mathrm{r}<0,361$ berkisar antara $-0,16$ sampai 0,297 . Peneliti membuang pernyataan yang tidak valid tersebut dengan alasan pernyataan valid masih dapat mewakili pernyataan yang terbuang. Item pernyataan menjadi 25 pernyataan. Langkah selanjutnya dilakukan uji reliabilitas dan memperoleh nilai Alpha Cronbach's= 0,967. dimana nilai tersebut lebih besar dari $r$ tabel $(0,361)$ sehingga pernyataan pada kuesioner $\mathrm{C}$ dinyatakan reliable. Uji normalitas data hasil penelitian menggunakan uji Kolmogorov Smirnov dan didapatkan hasil data berdistribusi tidak normal ( nilai $\mathrm{p}$ value 0,00 jadi < $0,05)$ sehingga menggunakan nilai median (Hidayat, 2009).

\section{Hasil}

Pengelolaan pasien HIV/ AIDSoleh perawat disajikan pada tabel 1. Sedangkan Distribusi frekuensi pengelolaan pasien HIV/ AIDS disajikan pada tabel 2 beikut ini. 
Jurnal Perawat Indonesia, Volume 2 No 2, Hal 78 - 82, November 2018 Persatuan Perawat Nasional Indonesia Jawa Tengah

Tabel 1.

Pengelolaan pasien HIV/AIDS oleh perawat pelaksana $(n=58)$

\begin{tabular}{cccccc}
\hline Variabel & Mean & Median & S.D & Min-Max & $95 \%(\mathrm{CI})$ \\
\hline Pengelolaan pasien HIV/AIDS & 62,36 & 64 & 5,884 & $39-70$ & $60,81-63,91$ \\
\hline
\end{tabular}

Tabel 2.

Distribusii frekuensi pengelolaan pasien HIV/AIDS ( $\mathrm{n}=58$ )

\begin{tabular}{lcc}
\hline \multicolumn{1}{c}{ Variabel } & Frekuensi & Persentase (\%) \\
\hline Pengelolaan pasien HIV/AIDS & & \\
- Baik & 31 & 53,4 \\
- Kurang baik & 27 & 46,6 \\
\hline
\end{tabular}

\section{Pembahasan}

Perawat memegang peranan penting dalam proses pengobatan, perawatan, dan dukungan pasien HIV/AIDS. Pelaksanaan tindakan perawatan didasarkan pada pedoman asuhan keperawatan pasien HIV/AIDS yang dilakukan secara terpadu, meliputi upaya-upaya promotif, preventif, kuratif, dan rehabilitatif. (Brunner and Suddarth's 2002). Pengelolaaan pasien HIV/AIDS meliputi kegiatan dari proses pengkajian sampai dengan evaluasi. Hasil penelitian menunjukkan bahwa pengelolaan pasien HIV/AIDS oleh perawat di RSUD dr. H.Soewondo Kendal sebagian besar lebih berada pada kriteria baik yaitu 53,4\%. Hal tersebut ditunjukkan dengan hasil sebaran kuesioner dari pernyataan perawat pelaksana bahwa perawat telah melakukan pengkajian pada status respiratori, nutrisi,tanda-tanda infeksi oportunistik dan pengetahuan pasien dan keluarga pasien tentang penyakit dan cara penularan $(93,1 \%-98,3 \%)$. Hasil temuan tersebut menunjukkan bahwa tahapan proses pengkajian mayoritas sudah dilakukan oleh perawat pelaksana.

Perawat merumuskan diagnosa keperawatan pasien HIV/AIDS berdasarkan hasil pengkajian yang dilakukan $(98,3 \%)$, hal ini menunjukkan tahapan kedua merumuskan diagnosa keperawatan mayoritas perawat sudah dilakukan. Pada saat mengelola pasien HIV/AIDS perawat berkoordinasi dengan tim kesehatan lain yaitu dengan petugas
Dinas Kesehatan Kabupaten Kendal. Perawat memberikan penjelasan pentingnya melakukan tindakan pencegahan penularan penyakit pada keluarga $(98,3 \%)$ yang bertujuan agar dalam melaksanakan asuhan keperawatan dapat berjalan berkesinambungan sesuai dengan rencana keperawatan. Perawat pada saat membuang sampah sudah disendirikan antara sampah non medis dan sampah medis $100 \%$ ), hal tersebut bertujuan untuk mencegah terjadinya infeksi nosokomial di Rumah Sakit.

Proses evaluasi 98,3\% perawat melakukan kegiatan tersebut dengan menanyakan respon pasien dan keluarga mengenai asuhan keperawatan yang telah diberikan selama perawatan di RS, kegiatan ini bertujuan untuk mendapatkan respon pasien dan keluarga setelah dilakukan asuhan keperawatan. Jadi pengelolaan pasien dengan HIV/AIDS oleh perawat pelaksana di RSUD dr. $\mathrm{H}$. Soewondo Kendal sebagian besar lebih sudah dilakukan dengan baik. Menurut peneliti hal tersebut di karenakan Rumah Sakit Umum Kendal saat ini sedang berbenah diri untuk meningkatkan pengetahuan perawat dengan cara pemaparan intensif mengenai pengendalian penyakit infeksi dimana salah satunya adalah penyakit HIV/AIDS. Pendapat tersebut sesuai dengan penelitian yang dilakukan oleh Waluyo dkk bahwa sikap terhadap pasien HIV/AIDS berbeda antara perawat yang memiliki pelatihan HIV dan tidak. Perawat yang belum pernah 
mendapatkan pelatihan HIV stigma terhadap ODHA lebih tinggi sehingga mempengaruhi dalam pemberian asuhan keperawatan dikarenakan terdapa perilaku diskriminatif dan membedakan dengan pasien lain ( Waluyo, 2011).

Hasil penelitian juga menunjukkan bahwa pengelolan pasien HIV/AIDS di RSUD dr. H. Soewondo Kendal yang berada pada kategori kurang baik sebanyak 46,6\%. Berdasarkan sebaran jawaban responden terhadap instrumen pengelolaan pasien HIV/AIDS sebagian besar responden $(90 \%)$ terdapat perasaan cemas dan enggan ketika melakukan pengkajian pada pasien HIV/AIDS. Penelitian di Afrika Selatan oleh Delobelle dkk juga menyatakan bahwa sebagian besar responden $(58,6 \%)$ merasa khawatir tertular ketika merawat pasien HIV/AIDS dan menularkannya kepada keluarga dan orang-orang terdekat, sehingga bisa mempengaruhi kualitas pemberian asuhan keperawatan (Delobelle,Peter. Dkk HIV/AIDS. Knowledge, Attitudes, Practices And Perceptions Of Rural Nurses In South Africa Article In Journal Of Advanced Nursing. from Http://Www.Researchgate.Net/Publication/ 243669782009 diakses tanggal 16 April 2016).

69\% Hasil sebaran kuesioner berikutnya mengelola pasien HIV/AIDS berada di ruangan pasien ketika ada panggilan dari pasien atau keluarga dan waktu memberikan injeksi saja, di samping itu $84,5 \%$ reponden menyatakan ketika merawat pasien dengan HIV/AIDS fokus pada penanganan gejala klinis dan infeksi oportunistik, sedangkan peningkatan rasa percaya diri pasien tidak termasuk penanganan perawatan. Perawat pelaksana $65,5 \%$ ketika meletakkan linen kotor bekas pasien infeksius dan non infeksius dijadikan satu dalam satu tempat /kantong, ketika injeksi,86,2\% jarum bekas pasien HIV/AIDS masih ditutup kembali dengan dua tangan baru dibuang.

\section{Simpulan dan Saran}

Pengelolaan pasien HIV/AIDS oleh perawat pelaksana di RSUD dr. $\mathrm{H}$. Soewondo Kendal sebagian besar berada pada kriteria baik yaitu sebanyak 53,4\% . Perawat diharapkan selalu meningkatkan pengetahuan tentang Universal Precaution dan pengendalian penyakit infeksi misalnya tentang recapping jarum, pembuangan spuit, linen kotor dan lainlain. Di samping itu pelayanan yang diberikan harus berfokus pada pasien khususnya pasien HIV/AIDS, dengan lebih meningkatkan rasa caring pada pasien, menjaga aspek psikologis pasien supaya lebih percaya diri, menghormati nilai-nilai dari pasien HIV/AIDS.

\section{Daftar Pustaka}

Brunner \& Suddarth's. Medical Surgical Nursing (10th ed). Philadelphia. Lippincott \& Wilkins. 2002

Delobelle,Peter. Dkk HIV/AIDS. Knowledge, Attitudes, Practices And Perceptions Of Rural Nurses In South Africa Article In Journal Of Advanced Nursing. from Http://Www.Researchgate.Net/Publi cation/24366978 2009 diakses tanggal 16 April 2016

Hidayat, A.Aziz Alimul. Metodologi Penelitian Keperawatan Dan Teknik Analisis Data. Jakarta: Salemba Medika. 2009

Nursalam dan Ninuk Dian. Asuhan Keperawatan Pada Pasien Terinfeksi HIV/AIDS. Jakarta: Salemba Medika. 2013

Rekam Medik RSUD dr. H. Soewondo Kendal diperoleh pada tanggal 5 Juli 2015

Singru, S.A; Banerjee, A. Occupational exposure to blood and body fluids among health care workers in a teaching hospital in Mumbai, India. 
Indian Journal of Community Medicine. 2008

Waluyo, Agung Dkk. Perilaku Perawat Terhadap Orang Dengan HIV/AIDS Di Rumah Sakit Dan Puskesmas. Jurnal Keperawatan Indonesia Volume 14 No 2 Juli 2011
Yayasan Spiritia. Data Statistik Kasus HIV/AIDS Di Indonesia. Diakses pada tanggal 30 Juni 2015 from http://spiritia.or.id/dokumum.php 